\section{FOUNDATIONS OF THE NEW WORLD ORDER}

\author{
By SIR JOHN ORR, F.R.S. \\ Rowett Research Institute
}

$\mathrm{P}_{\mathrm{P}}^{\mathrm{o}}$ OST-WAR economic reconstruction is neither possible nor desirable. We reconstructed after the War of 1914-18. The system wobbled in the world economic crisis of 1929 ; it has now crashed in the present War. Its doom is deserved. A system which, of set purpose in the interest of a few, limited the production and distribution of food and other necessities of life urgently needed by the vast majority of men, is incompatible with human welfare. With the old economic system goes its superstructure, the international political system under which we have suffered two world wars in one generation. The old world order is in its death throes.

Piecemeal planning for such limited objectives as the restoration of the sovereign rights of small States, the adjustment of political boundaries for a new balance of power or, in the economic field, for new trade agreements and the restitution of trade union rights, on the assumption that after the War things will be pretty much as they were before, is worse than a waste of time. It diverts men's minds from the real task, which is the building of the new world in which all men in all lands will enjoy the freedom from fear and freedom from want promised in the sixth article of the Atlantic Charter.

The old world, which had within it both good and evil, is undergoing a metamorphosis. The good and the evil are struggling for supremacy. The call of the new world is a challenge to the human race. Has man the higher spiritual attributes needed to build it ? Has he the intelligence to recognize irreversible changes now taking place in human society and the goodwill to direct these changes along lines calculated to promote human welfare ?

An evident irreversible change is the transition to a World State. Science has eliminated distance. To-day, the countries of the world are in closer contact than two adjacent counties in England were a hundred years ago. Phases of a World Government have been evolving rapidly since the time the first steamship crossed the Atlantic. Finance, trade, science and even sport have come under some form of international control, and Governments have united in organizations, such as those for the control of infectious diseases and an international postal system. The last phase will be the organization of a properly constituted Government based on a sound world economic policy with a world police to maintain law and order. This will carry through and complete the task begun half-heartedly when the League of Nations was set up after the War of 1914-18.

The real issue of the War is whether the World Government will be the kind imposed by the Nazis in Europe, which means a throw-back to the more primitive form of social order based on slavery and maintained by brute force, or a democratic Government in which nations will eo-operate for their mutual benefit.

The Nazis have an advantage in the struggle because they fully realize they are fighting for world dominion and they have created an enthusiasm among the German youth for their new world in which they will be the Herrenvolk. We, on the other hand, while willing to fight to the death to defend ourselves against Nazism, have no clear vision of the future to enthuse our own people and the people of all other lands for an offensive war as, a crusade to establish the new and better world. We have not yet even reached agreement on the kind of world we are fighting for.

The only way to reach agreement is to go back to fundamentals. All men of goodwill would agree that the first duty of Government is to provide the necessities of life for the people governed. The material necessities of life are (1) food and (2) shelter, which includes a house, furniture, clothing and warmth. To these must be added (3) work, which is a psychological necessity. The British Commonwealth, the United States, the U.S.S.R., China and all the other nations opposing Nazism could reach agreement on a simple positive programme based on providing the necessities of life for the people.

This may appear a rather meagre programme. As a matter of fact, even in the wealthiest countries, we could not complete this programme in less than ten years. A third of the population in the United Kingdom and about an equal proportion in the United States do not enjoy food and shelter on the standard needed for health. In most other countries, the proportion of the population which has never been adequately fed or adequately housed is even higher. Among native races, for whose welfare Britain is responsible, only a relatively small proportion of the population have reached that economic level.

If every family had a home in which they could live in decency, food on the health standard and a feeling of absolute security that they would never fall below that level, we should have an economic and social foundation upon which we could begin to build a new world which, in time, would provide for a still fuller life.

This simple plan of providing for human needs on a health standard has the great advantage that we know what we are planning for. The needs are known. We can measure them and estimate the time it will take to provide them.

I have outlined elsewhere a national food policy which would fit in with the world plan and would enable post-war food relief for Europe to dovetail smoothly into a permanent policy. The scheme suggested would involve less interference with the freedom and initiative of the farmer and trader than was involved with the pre-war marketing board schemes.

While food can be planned on a world scale, housing varies so much with climate that it is a national problem. In Great Britain the only way to get all families housed in our day is by a temporary housing scheme. In Scotland, after seventeen years of Government housing schemes, during which 280,000 houses were built, there were still 250,000 families needing decent homes. This was the position just before the War. 'The number needed by the end of the War may be about 400,000. In England it will be more than 2,000,000. These families cannot wait for a home until we have completed plans for the better location of industry and for new towns. A temporary housing scheme, providing houses on a minimum standard of whatever material is available, should be undertaken immediately the fighting finishes. An advantage of a temporary scheme is that it would give time to see what industries are likely to be after the War and where they can best be located. Within, say, ten years, these houses 
could be replaced by more permanent and better houses. We need not worry about the waste involved in a temporary housing scheme. Our capacity for production after the War will be increased to such an extent that there will be difficulty in getting an outlet for the products. In any event, the waste of human life involved by existing slum conditions is more important than the waste of material.

As Mr. Roosevelt has pointed out, the standard of living of the masses of the people is so low that if we undertook to provide satisfactory homes and adequate food for everybody, there would be work for every man and woman seeking a job. But provision must be made for men temporarily out of employment, and every man, rich or poor, should be made to do some useful work. A National Service Corps would provide for this. The men in the Corps could be employed on national or local government work. Every man should be forced to serve for a year before he reaches twenty-one years of age. After a year's service, a man would be free to leave. He would also be free to return if he wished and could not find employment. After a man had served a number of years calculated to be sufficient to pay for the bare necessities of life on a health standard for himself and his family, he could retire and enjoy these with the same dignity and self-respect as a man drawing an endowment for which he had paid all the premiums.

This plan for adequate food, a decent home and security for every family would bring about a social revolution. Bringing food and housing among the poorest third of the population up to the standard for health would reduce disease and improve national health and physique. Poverty in the old sense of the term would be gone for ever. A great part of our social and public health services and most of our charities would become unnecessary. The unemploy. ment problem would be solved. Every family would have security for a good home. For the first time in history, the common man would enjoy economic freedom and the means of attaining his full physical and spiritual manhood.

This plan would also lay the foundation for agricultural and economic prosperity. It is estimated that in the United States the production of the protective foods, for example, milk, eggs and fruit, would need to be increased from 15 per cent in the case of some to 100 per cent in the case of others. Similar increases are required for Britain and larger increases for most other countries. The production of this additional food would call for a great expansion of agriculture. To enable agriculture to produce the food needed the great majority of farms in Britain would need to be re-equipped. The same is true of almost all other countries, including . the United States. The re-equipment of agriculture would provide an outlet for an enormous amount of industrial products. When production had reached a level which would supply human needs there will be a permanent increase in the trade in food and in the commodities exchanged for food. A food policy based on human needs would be the spear-head for agricultural and economic prosperity.

$\Lambda$ policy of providing first for human needs, as outlined here, would be so revolutionary and so beneficial that it would be wise to concentrate on it and leave all industries not directly concerned with the necessities of life to the free play of private enter. prise. This would provide for the llexibility needed for the adjustment of industry and trade to the advances of scienoe.
This plan for building the new world from the bottom upwards would give expression to our growing spiritual idealism. Every great spiritual awakening calls for sacrifice. This plan involves sacrifice. In Britain those who already enjoy the necessities of life on a health standard-and that includes the well-paid workman-would need to stand back from the national table until those worse off are served. To accomplish the world food plan, the wealthy nations must give to the poor nations food, agricultural equipment and the other things needed to provide the necessities of life, not against a loan which would sink the poorer nations in debt, but on a world-wide lease-lend plan arranged by an international financial organization, the security of which would be guaranteed by all nations, including the poorest. The poorer nations would not be encouraged to pay interest in the form of money or exports which would delay the provision of the necessities of life on a health standard for the whole of their population. When they had reached that level, they could begin to pay their debt in money or in kind. The nations would find their spiritual and economic salvation in this policy of giving.

This may seem Utopian. It is merely the policy of the good neighbour. Any ordinary citizen would give food to a neighbour needing it, demanding nothing in exchange immediately. Until Governments in their dealing with each other reach the moral standard which regulates neighbourly relations, the world will never be free from war.

The adoption of this plan would remove the feeling of uncertainty and apprehension as to what is going to happen after the War. Everyone would know what they were fighting for and working for. The people in the occupied countries in Europe and even in Germany itself would know what our peace aims are. They could be told incessantly, day and night, that when our armies invade Europe they will bring the food ships with them, and that the United Nations will continue to send food and other things needed not merely for post-war relief but until each country, including Germany, is in a position to provide the necessities of life on a health standard for the whole population. We could, in terms which would carry conviction, call upon the people of all countries to join with the armies of the free to carry through the glorious revolution for the destruction of the forces of evil, and the establishment of a new World Order in which the nations will co-operate to bring freedom from the fear of war and freedom from want to all men in all lands.

\section{QUANTUM THEORY AND DIFFUSE X-RAY REFLEXIONS}

T the article by Mr. G. D. Preston which appeared 1 in Nature of April 4, a descriptive account was given of the theory put forward by Sir C. V. Raman in a series of papers published in the Proceedings of the Indian Academy of Sciences to explain the extra spots on Laue and other types of X-ray photographs. We here adopting a much more critical attitude.

Raman has emphasized the fact that when X-rays are scattered by a vibrating system, the scattered beam contains components of changed frequency. It is not, however, made clear either in the Symposium or in Preston's account of it that this is a consequence 